\title{
Apoptotic effect of $\mathrm{IP}_{6}$ was not enhanced by co-treatment with myo-inositol in prostate carcinoma PC3 cells
}

\author{
Hyun-Jung Kim, Yu-mi Jang, Harriet Kim and Young Hye Kwon ${ }^{+\S}$ \\ Department of Food and Nutrition, ${ }^{+}$Research Institute of Human Ecology, Seoul National University, Seoul 151-742, Korea
}

Received August 6, 2007; Revised September 2, 2007; Accepted September 13, 2007

\begin{abstract}
Inositol hexaphosphate $\left(\mathrm{IP}_{6}\right)$ is a major constituent of most cereals, legumes, nuts, oil seeds and soybean. Previous studies reported the anticancer effect of $\mathrm{IP}_{6}$ and suggested that co-treatment of $\mathrm{IP}_{6}$ with inositol may enhance anticancer effect of $\mathrm{IP}_{6}$. Although the anticancer effect of $\mathrm{IP}_{6} \mathrm{has}$ been intensively studied, the combinational effect of $\mathrm{IP}_{6}$ and inositol and involved mechanisms are not well understood so far. In the present study, we investigated the effect of $\mathrm{IP}_{6}$ and myo-inositol (MI) on cell cycle regulation and apoptosis using PC3 prostate cancer cell lines. When cells were co-treated with $\mathrm{IP}_{6}$ and $\mathrm{MI}$, the extent of cell growth inhibition was significantly increased than that by $\mathrm{IP}_{6}$ alone. To identify the effect of $\mathrm{IP}_{6}$ and $\mathrm{MI}$ on apoptosis, the activity of caspase-3 was measured. The caspase-3 activity was significantly increased when cells were treated with either $\mathrm{IP}_{6}$ alone or both $\mathrm{IP}_{6}$ and $\mathrm{MI}$, with no significant enhancement by co-treatment. To investigate the effect of $\mathrm{IP}_{6}$ and $\mathrm{MI}_{\text {of cell cycle }}$ arrest, we measured p21 mRNA expression in PC3 cells and observed significant increase in p21 mRNA by $\mathrm{IP}_{6}$. But synergistic regulation by co-treatment with $\mathrm{IP}_{6}$ and $\mathrm{MI}$ was not observed. In addition, there was no significant effect by co-treatment compared to $\mathrm{IP}_{6}$ treatment on the regulation of cell cycle progression although $\mathrm{IP}_{6}$ significantly changed cell cycle distribution in the presence of $\mathrm{MI}$ or not. Therefore, these findings support that $\mathrm{IP}_{6}$ has anticancer function by induction of apoptosis and regulation of cell cycle. However, synergistic effect by MI on cell cycle regulation and apoptosis was not observed in PC3 prostate cancer cells.
\end{abstract}

Key Words: Inositol hexaphosphate, myo-inositol, apoptosis, prostate cancer, cell cycle progression

\section{Introduction}

Inositol hexaphosphate $\left(\mathrm{IP}_{6}\right)$, which is also known as phytic acid, is a major constituent of most cereals, legumes, nuts and soybean. In plants, phytic acid exists as salt with monovalent and divalent cations (Shamsuddin et al., 1997). $\mathrm{IP}_{6}$ and lower phosphorylated inositols $\left(\mathrm{IP}_{1-5}\right)$ are also found in almost all mammalian cells in substantial amounts up to $1 \mathrm{mM}$ (Sasakawa et al., 1995; Shamsuddin, 1999). The second messenger role of inositol 1,4,5-trisphosphate $\left(\mathrm{IP}_{3}\right)$ in bringing about a host of cellular functions including mitosis via mobilizing intracellular $\mathrm{Ca}^{2+}$ is well recognized. Inositol 1,3,4,5-tetraphosphate $\left(\mathrm{IP}_{4}\right)$ and inositol 1,3,4,5,6-pentaphosphate $\left(\mathrm{IP}_{5}\right)$ have been shown to induce $\mathrm{Ca}^{2+}$ sequestration (Shamsuddin et al., 1997). Recently, many studies have shown several health benefits of $\mathrm{IP}_{6}$ and anticancer efficacy of $\mathrm{IP}_{6}$ has been observed both in vivo and in vitro studies (Vucenik \& Shamsuddin, 2003). $\mathrm{IP}_{6}$ inhibited tumor growth by induction of apoptotic cell death, cell cycle arrest and differentiation of several human cancer cell lines including colon (Sakamoto et al., 1993), liver (Vucenik et al., 1998a), prostate (Singh et al., 2003; Zi et al., 2000) and breast (Shamsuddin et al., 1996; Vucenik et al., 2005). Also, the ability of $\mathrm{IP}_{6}$ to reduce the incidence and multiplicity of mammary tumors has been demonstrated in a variety of animal models including chemical-induced (Estensen \& Wattenberg, 1993; Vucenik et al., 1995) and transplanted tumor model (Singh et al., 2004; Vucenik et al., 1998b).

Inositol phosphates are synthesized from the parent molecule inositol, and it is estimated that adults consume approximately $1 \mathrm{~g}$ of inositol per day (Shamsuddin et al., 1997). Myo-inositol (MI) is a parent compound of $\mathrm{IP}_{6}$ and has been found in plants (Reddy et al., 1982). The addition of inositol, a precursor of inositol phosphates, to $\mathrm{IP}_{6}$ have been shown to enhance the anticancer function of $\mathrm{IP}_{6}$ in vivo (Shamsuddin et al., 1989; Vucenik et al., 1995). The synergistic effect may be by which $\mathrm{IP}_{6}$ plus inositol exerts their action via lower-phosphate inositol phosphates, which serve as intracellular second messengers. Measurement of intracellular inositol phosphates after $\mathrm{IP}_{6}$ treatment showed inconsistent change regarding lower-phosphate inositol phosphates. When rats were fed AIN-76A $+1 \% \mathrm{IP}_{6}$ diet for 12 weeks, there were no significant changes in the $\mathrm{IP}_{3}$ contents depending on $\mathrm{IP}_{6}$ ingestion in food, while the levels of $\mathrm{IP}_{6}$ in both brain and plasma were very sensitive to its presence in the diet (Grases et al., 2002). However, in human malignant cell lines following $\mathrm{IP}_{6}$ treatment, the increases in intracellular levels of $\mathrm{IP}_{3}$ or other lower phosphorylated inositols have suggested

${ }^{\S}$ Corresponding Author: Young Hye Kwon, Tel. 82-2-880-6833, Fax. 82-2-884-0305, Email. hye0414@snu.ac.kr 
the important role of these metabolites as mediators of anti-cancer action of $\mathrm{IP}_{6}$ (Ferry et al., 2002; Grases et al., 2002). In fact, cell proliferation was inhibited by inositol 1,3,4,5,6-pentaphosphate and inositol 1,4,5,6-tetraphosphate at micromolar concentrations in various cancer cells (Ferry et al., 2002; Razzini et al., 2000).

Although several studies using animal models showed the synergistic effect of $\mathrm{IP}_{6}$ and inositol, the synergistic effect and involved mechanism are far for being understood in cancer cell lines. Therefore, in the present study, we treated PC3 cell lines with $\mathrm{IP}_{6}$ and $\mathrm{MI}$ to investigate the synergistic effect along with the involved molecular mechanism.

\section{Materials and Methods}

\section{Cell culture and treatment}

The androgen-independent human prostate cancer cell line PC3 was obtained from the KCLB (Seoul, Korea). Cells were cultured in RPMI 1640 medium supplemented with $10 \%$ fetal bovine serum (Cambrex, USA), 100 units $/ \mathrm{ml}$ penicillin, and $100 \mu \mathrm{g} / \mathrm{ml}$ streptomycin at $37^{\circ} \mathrm{C}$ in a humidified $5 \% \mathrm{CO}_{2}$ incubator (Sanyo, Japan). Cells were cultured for $24 \mathrm{~h}$ after plating and treated with $\mathrm{IP}_{6}(0.5,1 \mathrm{mM})$ and/or $\mathrm{MI}(5,10 \mathrm{mM})$ dissolved in complete culture medium for $48 \mathrm{~h}$. $\mathrm{IP}_{6}$ and $\mathrm{MI}$ were purchased from Sigma-Aldrich (USA).

\section{Determination of cell growth}

After treatment, cells were washed with PBS and collected by a brief trypsinization, stained with $0.4 \%$ trypan blue (Invitrogen, USA), and unstained cells were counted in duplicate with a hemacytometer. The effect of each treatment on growth inhibition was assessed as the percentage of inhibition in cell growth where control cells were taken as $100 \%$ viable.

\section{Cell cycle phase distribution by flow cytometry}

The effect of $\mathrm{IP}_{6}$ on cell cycle phase distribution was assessed using flow cytometry. Briefly, after treatment of cells, floating cells were collected and the attached cells were trypsinized and washed twice with cold PBS. Thereafter, floating cells were combined with washed attached cells and total cells were centrifuged at $100 \mathrm{~g}$ for $5 \mathrm{~min}$, pellet was resuspended in PBS containing albumin. Resuspended cells were mixed in $70 \% \mathrm{EtOH}$ and stored at $-20^{\circ} \mathrm{C}$ until analysis. For analysis, cells were centrifuged and resuspended in PBS with RNAase at $37^{\circ} \mathrm{C}$ for $30 \mathrm{~min}$. The cells were then chilled over ice for $10 \mathrm{~min}$ and stained with propidium iodide ( $50 \mu \mathrm{g} / \mathrm{ml}$ final concentration) for $1 \mathrm{~h}$ for analysis by flow cytometry. Flow cytometry was performed with a FACScan (Becton Dickinson, Germany).
Measurement of $m R N A$ levels by semiquantitative RT-PCR

Total RNA was isolated from the cells using Trizol (Invitrogen, USA) and RNA concentration was measured spectrometrically at $260 \mathrm{~nm}$. The quality of RNA was also determined by running MOPS-RNA gel and the integrity of two bands was assured. Total cellular RNA was isolated using Trizol Reagent (Invitrogen, USA) and cDNA was synthesized using $2 \mu \mathrm{g}$ of total RNA with the Superscript ${ }^{\mathrm{TM}}$ First-strand synthesis system (Invitrogen, USA). For amplification of cDNA, primers for p21 (upstream primer, GACAGCAGAGGAAGACCAT; downstream primer, TGGAGTGGTAGAAATCTGTCAT; $55^{\circ} \mathrm{C}$ ) were used. Expression of $\beta$-actin was examined as an internal control (upstream primer, GTTTGAGACCTTCAACACCCC; downstream primer, GTGGCCATCTCCTGCTCGAAGTC; $60^{\circ} \mathrm{C}$ ). For each combination of primers, the kinetics of PCR amplification was studied, the number of cycles corresponding to plateau was determined, and PCR was performed within the exponential range. Amplified products were separated on an agarose gel and visualized with ethidium bromide staining. The results were quantitated using Fluor-S ${ }^{\mathrm{TM}}$ Multilmager (Bio-Rad, USA).

\section{Determination of caspase-3 activities}

The activity of caspase- 3 was measured by Caspase- 3 colorimetric assay kit (MBL, USA). Briefly, after treatment, cells were collected and lysed. One hundred micrograms of cell lysates were loaded into 96-well microplates, and mixed with reaction buffer and substrate for $2 \mathrm{~h}$ in an incubator at $37^{\circ} \mathrm{C}$. Absorbance was measured using a multiwell reader (Bio-Rad, USA) at $405 \mathrm{~nm}$ every $30 \mathrm{~min}$ to confirm the linearity of absorbance. Protein content was determined using the Bio-Rad protein assay reagent (Bio-Rad, USA). Caspase-3 activity was first expressed as change in absorbance units per microgram protein and per hour and then converted to the relative value compared to control.

\section{Statistical methods}

The data were analyzed using SAS software. For all experiments, one-way ANOVA followed by Duncan's multiple range test was employed to asses the statistical significance. Data were expressed as mean \pm SEM and statistical significant difference was considered to be present at $\mathrm{p}<0.05$.

\section{Results}

PC3 cells were cultured for $24 \mathrm{~h}$ after plating and various concentrations of $\mathrm{IP}_{6}$ and $\mathrm{MI}$ were added to the well, followed by further incubation for $48 \mathrm{~h}$. Viable cell numbers were counted manually by hemocytometer after trypan blue staining. As shown in Fig. 1, $\mathrm{IP}_{6}$ treatment inhibited the growth of human prostate carcinoma PC3 cells in a dose-dependent manner. Treatment of 


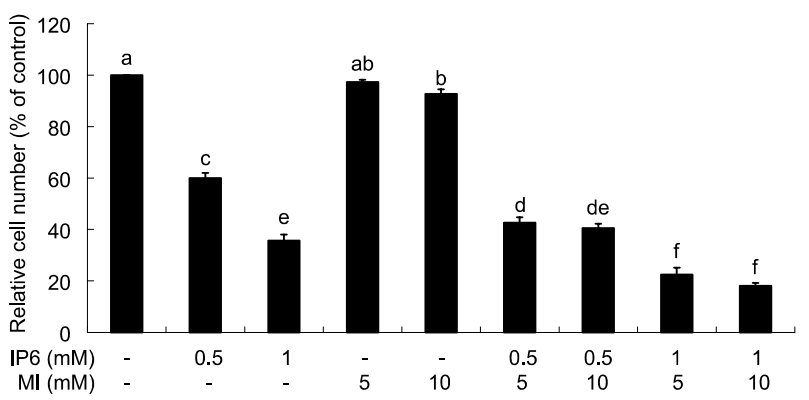

Fig. 1. Effects of IP6 and MI on inhibition of PC3 cell growth. Twenty-four hours after plating, cells were treated with IP6, Ml, or IP6 plus Ml at concentrations as described for $48 \mathrm{~h}$. After treatment, cells were harvested and cell numbers were estimated by trypan blue exclusion method. Each bar represents mean $\pm \mathrm{SEM}$ $(n=3)$ and bars with different superscripts are significantly different at $p<0.05$.

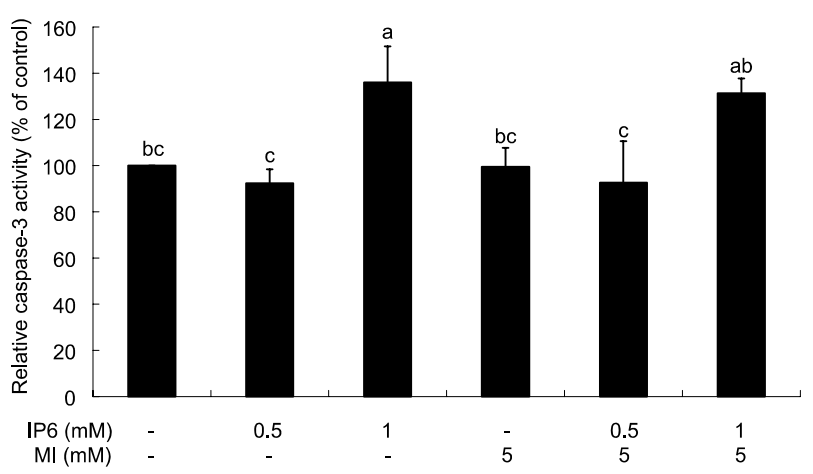

Fig. 2. Effects of of $I_{6}$ and $M I$ on apoptosis of PC3 cells. Twenty-four hours after plating, cells were treated with $\mathrm{IP}_{6}, \mathrm{Ml}$, or $\mathrm{IP}_{6}$ plus $\mathrm{Ml}$ at concentrations as described for $48 \mathrm{~h}$. Caspase-3 activity was measured using colorimetric assay kit and the resulting data is expressed as percentage of the control value. Each bar represents mean \pm SEM $(n=3)$ and bars with different superscripts are significantly different at $p<0.05$.

cells with $10 \mathrm{mM}$ MI significantly affected on cell number, but no significant effect on cell growth was observed by $5 \mathrm{mM}$ MI. When cells were co-treated with $\mathrm{IP}_{6}$ and $\mathrm{MI}$, cell growth was significantly decreased compared to those in cells treated with either $\mathrm{IP}_{6}$ or MI. However, additional inhibitory effect by different concentrations of MI treatment was not observed.

To determine the involved mechanism regarding decreased number of cells, we investigated apoptotic effect by $\mathrm{IP}_{6}$ and/or MI by measurement of caspase-3 activity. As shown in Fig. 2, $1 \mathrm{mM} \mathrm{IP}_{6}$ only and $1 \mathrm{mM} \mathrm{IP}_{6}$ plus $5 \mathrm{mM}$ MI treatments significantly increased the activity of caspase- 3 , suggesting the possible involvement of caspase activation as one of the possible mechanisms of apoptosis induction. However, we could not observe apoptotic effect by MI alone. In addition, synergistic effect by $\mathrm{IP}_{6}$ and MI co-treatment on caspase-3 activity was not observed.

We measured p21 mRNA expression to investigate the involvement of cell cycle arrest in the inhibition of cell growth by $\mathrm{IP}_{6}$ and $\mathrm{MI}$ co-treatment. Eukaryotic cell cycle progression is regulated by sequential activation of various CDKs, which activities are dependent on their association with corresponding cyclins and cyclin-dependent kinase inhibitors (CDKI) (Morgan,
(A)

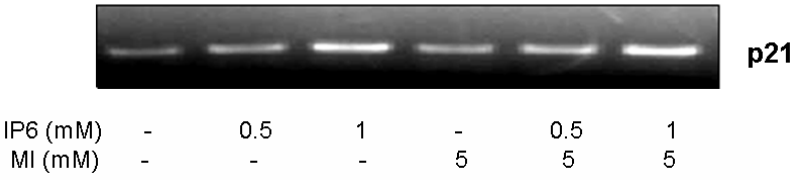

(B)

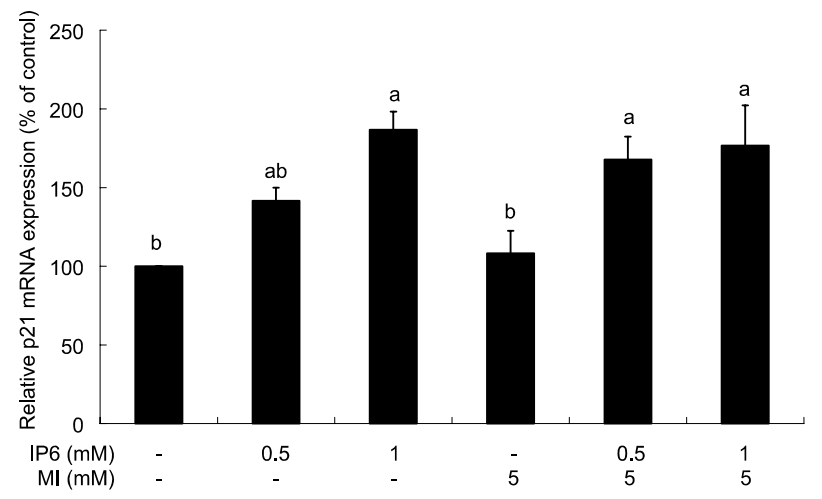

Fig. 3. Effects of $\mathrm{IP}_{6}$ and $\mathrm{MI}$ on the $\mathrm{p} 21 \mathrm{mRNA}$ expression. Twenty-four hours after plating, cells were treated with $\mathrm{IP}_{6}, \mathrm{Ml}$, or $\mathrm{I}_{6}$ plus $\mathrm{Ml}$ at concentrations as described for $48 \mathrm{~h}$. (A) Representative photographs of 3 independent experiments are shown. (B) The relative abundance of p21 was quantified with the control level set at $100 \%$. Each bar represents mean $\pm \operatorname{SEM}(n=3)$ and bars with different superscripts are significantly different at $p<0.05$.

Table 1. Effects of $\mathrm{IP}_{6}$ and $\mathrm{Ml}$ on $\mathrm{PC} 3$ cell cycle distribution

\begin{tabular}{|c|c|c|c|c|}
\hline \multirow{2}{*}{ Treatment } & \multicolumn{4}{|c|}{$\%$ Cells } \\
\hline & Sub G0/G1 & G0/G1 & S & $\mathrm{G} 2 / \mathrm{M}$ \\
\hline Control & $1.65 \pm 0.17^{c}$ & $49.70 \pm 0.98^{a}$ & $15.44 \pm 0.51^{\mathrm{a}}$ & $29.11 \pm 0.81^{b}$ \\
\hline $0.5 \mathrm{mM} \mathrm{IP}_{6}$ & $4.68 \pm 0.23^{b}$ & $47.75 \pm 1.27^{\mathrm{a}}$ & $13.24 \pm 0.33^{b}$ & $29.61 \pm 0.97^{\mathrm{ab}}$ \\
\hline $1 \mathrm{mM} \mathrm{IP}_{6}$ & $8.43 \pm 0.79^{\mathrm{a}}$ & $43.89 \pm 0.85^{b}$ & $11.82 \pm 0.54^{\mathrm{bc}}$ & $31.23 \pm 0.71^{a b}$ \\
\hline $5 \mathrm{mM} \mathrm{Ml}$ & $1.72 \pm 0.31^{\mathrm{C}}$ & $48.39 \pm 1.31^{a}$ & $14.90 \pm 0.86^{a}$ & $30.51 \pm 0.82^{\mathrm{ab}}$ \\
\hline $0.5 \mathrm{mM} \mathrm{IP}_{6}+5 \mathrm{mM} \mathrm{Ml}$ & $5.06 \pm 0.50^{\mathrm{b}}$ & $48.64 \pm 1.46^{a}$ & $12.29 \pm 0.37^{b c}$ & $29.45 \pm 0.99^{b}$ \\
\hline $1 \mathrm{mM} \mathrm{IP}_{6}+5 \mathrm{mM} \mathrm{MI}$ & $8.53 \pm 1.53^{\mathrm{a}}$ & $42.94 \pm 1.22^{b}$ & $11.11 \pm 0.59^{c}$ & $33.17 \pm 2.01^{a}$ \\
\hline
\end{tabular}

Cells were treated with various concentrations of $\mathrm{IP}_{6}$ or $\mathrm{Ml}$ for $48 \mathrm{~h}$. Both floating and attached cells were collected and processed for analysis of cell cycle distribution by flow cytometry following staining with propidium iodide. Data are means \pm SEM $(n=5)$. Means with different superscripts are significantly different at $p<0.05$ by Duncan's multiple range test.

1995). As shown in Fig. 3, there was an upregulation of p21 mRNA level after $\mathrm{IP}_{6}$, which is consistent with the previous study using LNCaP cells (Agarwal et al., 2004). However, there was no significant difference in p21 mRNA level between $\mathrm{IP}_{6}$ treatment only and $\mathrm{IP}_{6}$ and $\mathrm{MI}$ co-treatment.

Because cell cycle progression is an essential event for cellular growth, we also examined whether the cell growth inhibitory effect by $\mathrm{IP}_{6}$ and/or $\mathrm{MI}$ is mediated through an alteration in a specific phase of the cell cycle progression. For this experiment, flow cytometric analysis of cells (both attached and floating cells) was conducted after staining cells with propidium iodide. Table 1 summarized the effect of $\mathrm{IP}_{6}$ and/or MI treatment on the cell cycle distribution of PC3 cells. Treatment of cells with $1 \mathrm{mM}$ $\mathrm{IP}_{6}$ significantly changed cell cycle phase distribution compared 
to that of control group by increasing cells in sub G0/G1 and by decreasing cells in G0/G1 and S phases. Although we also observed significant changes in cell cycle distribution by co-treatment with $1 \mathrm{mM} \mathrm{IP} 6$ and $5 \mathrm{mM}$ inositol, there was no significant difference in cell cycle phase distribution between $\mathrm{IP}_{6}$ treatment only and $\mathrm{IP}_{6}$ and $\mathrm{MI}$ co-treatment.

\section{Discussion}

Although the anticancer effect of $\mathrm{IP}_{6}$ has been intensively studied, the combinational effect of $\mathrm{IP}_{6}$ and inositol and the involved mechanisms are not well understood so far. Therefore, we investigated the effect of co-treatment of $\mathrm{IP}_{6}$ and MI, which are easily consumed by the same diet such as soy, on apoptotic cell death and cell cycle regulation of prostate cancer cell PC3.

In the present study, we could not observe the significant anticancer effect of inositol on prostate cancer cell line. Although its effect was shown in some in vivo studies, its efficacy was different depending on the type of cancer (Estensen \& Wattenberg, 1993; Vucenik et al., 1995). Also, there has been no previous study investigating the effect of inositol on prostate cancer cell lines. In addition, we could not observe the synergistic effect of $\mathrm{IP}_{6}$ and inositol on apoptosis of PC3 cells. Several studies proposed the underlying mechanism of synergistic inhibition of cell proliferation as the increased synthesis of low number of IPs by stimulating dephosphorylation of $\mathrm{IP}_{6}$. When HeLa cells were treated with $\left[{ }^{3} \mathrm{H}\right] \mathrm{IP}_{6}$, the inhibition of cell growth was observed with increased synthesis of $\left[{ }^{3} \mathrm{H}\right] \mathrm{IP}_{4}$ and $\left[{ }^{3} \mathrm{H}\right] \mathrm{IP}_{5}$ (Ferry et al., 2002). In addition, when small cell lung cancer (SCLC) cells were treated with either $\mathrm{IP}_{4}$ or $\mathrm{IP}_{5}$, the cell growth was significantly decreased compared to that of cells treated with either $\mathrm{IP}_{3}$ or $\mathrm{IP}_{6}$ (Razzini et al., 2000). Therefore, further studies will be needed in the aspect of the synthesis of low number of IPs from co-treatment of $\mathrm{IP}_{6}$ and inositol.

Our data showed that caspase- 3 activity was significantly increased when cells were treated with $\mathrm{IP}_{6}$, which is consistent with previous studies using HeLa cells (Ferry et al., 2002) and PC3 cells (Diallo et al., 2006). These consistent increases in caspase- 3 activity by $\mathrm{IP}_{6}$ suggest that caspase activation might be the main mechanism of $\mathrm{IP}_{6}$-induced apoptosis in PC3 cells. The apoptotic effect by $\mathrm{IP}_{6}$ and/or MI is also consistent with FACS data, which also showed the significant increase in subG0 phase when cells were treated with either $\mathrm{IP}_{6}$ alone or $\mathrm{IP}_{6}$ and MI together.

Cell cycle arrest in either G1 phase or G2/M phase has been demonstrated as one of anticancer mechanism. Accordingly, we assessed the level of p21 mRNA and showed the significant change by combined treatments of $\mathrm{IP}_{6}$ and/or MI. As PC3 is a p53-negative cell line (Isaacs et al., 1991) unlike LNCaP cells, these modulations of proapoptotic proteins and induction of apoptosis were independent of p53. The previous study showed that $\mathrm{IP}_{6}(0.25-4 \mathrm{mM})$ induced $\mathrm{G} 1$ arrest, and, in time kinetics, maximum G1 arrest at $24 \mathrm{~h}$ of treatment, which was sustained significantly up to $72 \mathrm{~h}$ in DU145 cells (p53 ${ }^{\mathrm{mt} / \mathrm{mt}}$ ) (Singh et al., 2003). However, the G1 arrest was not observed in our study when cells were treated with $\mathrm{IP}_{6}$, which could be due to the use of different types of cancer cell lines. Although cell doubling time of PC3 and DU145 is shown about $40 \mathrm{~h}$ without significant difference between two cell lines (Diallo et al., 2006), the previous study showed different patterns of cell cycle alteration by the addition of selenium (Venkateswaran et al., 2002). In addition, PC3 cells are androgen-insensitive cells. A recent study showed that prostate cancer cells that did not express the androgen receptor were more sensitive to the effects of $\mathrm{IP}_{6}$ on cellular metabolism as well as apoptosis (Diallo et al., 2006). Therefore, the molecular mechanism of $\mathrm{IP}_{6}$ may be different in cancer cells representative of different malignancy grades and these differences might be explained by the distinct profile of steroid receptors present in various cell lines.

Taken together, the data presented in this work indicate that $\mathrm{IP}_{6}$ induces caspase-3-mediated apoptosis and p21-mediated cell cycle regulation. Although we observed synergistic inhibition of cell growth by $\mathrm{IP}_{6}$ and $\mathrm{MI}$ co-treatment, we could not observe differences in the regulation of cell cycle phase distribution as well as apoptosis by the addition of $\mathrm{MI}$ to $\mathrm{IP}_{6}$. Therefore, further studies regarding inhibitory effect by $\mathrm{IP}_{6}$ and $\mathrm{MI}$ co-treatment on tumor cell differentiation and tumor marker expression need to be investigated.

\section{Literature cited}

Agarwal C, Dhanalakshmi S, Singh R \& Agarwal R (2004). Inositol hexaphosphate inhibits growth and induces G1 arrest and apoptotic death of androgen-dependent human prostate carcinoma LNCaP cells. Neoplasia 6:646-659.

Diallo JS, Peant B, Lessard L, Delvoye N, Le Page C, Mes-Masson AM \& Saad F (2006). An androgen-independent androgen receptor function protects from inositol hexakisphosphate toxicity in the PC3/PC3(AR) prostate cancer cell lines. Prostate 66:1245-1256.

Estensen R \& Wattenberg L (1993). Studies of chemopreventive effects of myo-inositol on benzo[a]pyrene-induced neoplasia of the lung and forestomach of female A/J mice. Carcinogenesis 14: 1975-1977.

Ferry S, Matsuda M, Yoshida H \& Hirata M (2002). Inositol hexakisphosphate blocks tumor cell growth by activating apoptotic machinery as well as by inhibiting the Akt/NFkB-mediated cell survival pathway. Carcinogenesis 23:2031-2041.

Grases F, Simonet B, Vucenik I, Perello J, RM P \& Shamsuddin A (2002). Effects of exogenous inositol hexakisphosphate (InsP(6)) on the levels of $\operatorname{InsP}(6)$ and of inositol trisphosphate $(\operatorname{InsP}(3))$ in malignant cells, tissues and biological fluids. Life Sci 71: 1535-1546.

Isaacs W, Carter B \& Ewing C (1991). Wild-type p53 suppresses growth of human prostate cancer cells containing mutant p53 alleles. Cancer Res 51:4716-4720.

Morgan DO (1995). Principles of CDK regulation. Nature 974: 131-134. 
Razzini G, Berrie C, Vignati S, Broggini M, Mascetta G, Brancaccio A \& Falasca M (2000). Novel functional PI 3-kinase antagonists inhibit cell growth and tumorigenicity in human cancer cell lines. FASEB $J$ 14:1179-1187.

Reddy N, Sathe S \& Salunkhe D (1982). Phytates in legumes and cereals. Adv Food Res 28:1-92.

Sakamoto K, Venkatraman G \& Shamsuddin A (1993). Growth inhibition and differentiation of HT-29 cells in vitro by inositol hexaphosphate (phytic acid). Carcinogenesis 14:1815-1819.

Sasakawa N, Sharif M \& Hanley M (1995). Metabolism and biological activities of inositol pentakisphosphate and inositol hexakisphosphate. Biochem Pharmacol 50:137-146.

Shamsuddin A (1999). Metabolism and cellular functions of IP6: a review. Anticancer Res 19:3733-3736.

Shamsuddin A, Ullah A \& Chakravarthy A (1989). Inositol and inositol hexaphosphate suppress cell proliferation and tumor formation in CD-1 mice. Carcinogenesis 10:1461-1463.

Shamsuddin A, Vucenik I \& Cole K (1997). IP6: A novel anti-cancer agent. Life Sci 61:343-354.

Shamsuddin A, Yang G \& Vucenik I (1996). Novel anti-cancer functions of IP6: growth inhibition and differentiation of human mammary cancer cell lines in vitro. Anticancer Res 16:3287-3292.

Singh RP, Agarwal C \& Agarwal R (2003). Inositol hexaphosphate inhibits growth, and induces G1 arrest and apoptotic death of prostate carcinoma DU145 cells: modulation of CDKI-CDK-cyclin and pRB-related protein-E2F complexes. Carcinogenesis 24:555563.

Singh RP, Sharma G, Mallikarjuna G, Dhanalakshm S, Agarwal C \& Agarwal R (2004). In vivo suppression of hormone-refractory prostate cancer growth by inositol hexaphosphate: induction of insulin-like growth factor binding protein-3 and inhibition of vascular endothelial growth factor. Clin Cancer Res 10:244-250.

Venkateswaran V, Klotz LH \& Fleshner NE (2002). Selenium modulation of cell proliferation and cell cycle biomarkers in human prostate carcinoma cell lines. Cancer Res 62:2540-2545.

Vucenik I, Ramakrishna G, Tantivejkul K, Anderson L \& Ramljak D (2005). Inositol hexaphosphate (IP6) blocks proliferation of human breast cancer cells through a PKCdelta-dependent increase in p27Kip1 and decrease in retinoblastoma protein (pRb) phosphorylation. Breast Cancer Res Treat 91:35-45.

Vucenik I \& Shamsuddin A (2003). Cancer inhibition by inositol hexaphosphate (IP6) and inositol: from laboratory to clinic. $J$ Nutr 133:3778S-3784S

Vucenik I, Tantivejkul K, Zhang Z, Cole K, Saied I \& Shamsuddin A (1998a). IP6 in treatment of liver cancer. I. IP6 inhibits growth and reverses transformed phenotype in HepG2 human liver cancer cell line. Anticancer Res 18:4083-4090.

Vucenik I, Yang G \& Shamsuddin A (1995). Inositol hexaphosphate and inositol inhibit DMBA-induced rat mammary cancer. Carcinogenesis 16:1055-1058.

Vucenik I, Zhang Z \& Shamsuddin A (1998b). IP6 in treatment of liver cancer. II. Intra-tumoral injection of IP6 regresses pre-existing human liver cancer xenotransplanted in nude mice. Anticancer Res 18:4091-4096.

Zi X, Singh R \& Agarwal R (2000). Impairment of erbB1 receptor and fluid-phase endocytosis and associated mitogenic signaling by inositol hexaphosphate in human prostate carcinoma DU145 cells. Carcinogenesis 21:2225-2235. 